\title{
PENGARUH KREATIVITAS DAN KECERDASAN SPIRITUAL TERHADAP EFIKASI DIRI DAN KEMANDIRIAN MAHASISWA JURUSAN MANAJEMEN FAKULTAS EKONOMI UNIVERSITAS ISLAM MAJAPAHIT (UNIM) MOJOKERTO
}

\author{
Sundari, Pascasarjana Unesa \\ sundari.fairuzah@yahoo.com
}

\begin{abstract}
ABSTRAK
Penelitian ini bertujuan untuk menganalisis pengaruh kreativitas dan kecerdasan spiritual terhadap efikasi diri dan kemandirian mahasiswa. Obyek penelitian ini adalah mahasiswa jurusan manajemen Fakultas Ekonomi UNIM (Universitas Islam Majapahit) Mojokerto tahun ajaran 2013/2014. Jenis pengambilan sampel yang digunakan dalam penelitian ini adalah simple random sampling dan jumlah sampel yang digunakan sebanyak 113 orang. Adapun teknik pengumpulan data yang digunakan yaitu angket, wawancara, dan dokumentasi. Sedangkan metode analisis menggunakan teknik Structural Equation Modeling (SEM). Hasil penelitian menunjukkan bahwa kreativitas berpengaruh signifikan terhadap efikasi diri mahasiswa. Kreativitas berpengaruh signifikan terhadap kemandirian mahasiswa. Kecerdasan spiritual berpengaruh signifikan terhadap efikasi diri mahasiswa. Efikasi diri berpengaruh signifikan terhadap kemandirian mahasiswa. Sedangkan kecerdasan spiritual tidak berpengaruh terhadap kemandirian mahasiswa. Kreativitas tidak berpengaruh terhadap kemandirian melalui efikasi diri mahasiswa. Demikian juga kecerdasan spiritual tidak berpengaruh terhadap kemandirian melalui efikasi dirimahasiswa.
\end{abstract}

Kata Kunci: Kreativitas, Kecerdasan Spiritual, Efikasi Diri dan Kemandirian

\begin{abstract}
This study aims to analyze the influence of creativity and spiritual intelligence to the students self-efficacy. The object in this study were management students of the Economics faculty at UNIM management (Islamic University of Majapahit) Mojokerto 2013/2014. This study used Simple random sampling. The number of samples which were used in this study were 113 people. The data collection techniques used were questionnaires, interviews, and documentation. The method of analysis was Structural Equation Modeling (SEM). The results showed that creativity gives significant effect on students self-efficacy. Creativity influences independence. Spiritual intelligence influences students self-efficacy. Self-efficacy influences student independence. However, Spiritual intelligence does not affect the independence of the student. Creativity does not affect the independence through student self-efficacy. Spiritual intelligence does not affect the independence through self-efficacy.
\end{abstract}

Keywords: Creativity, Spiritual intelegence, self-efficacy, and Self-regulation 


\section{PENDAHULUAN}

Perkembangan ilmu pengetahuan dan teknologi yang pesat di era globalisasi saat ini, menghadapkan manusia pada situasi yang cepat berubah sehingga pergeseran nilai-nilai sosial dan budaya di tengah masyarakat tidak dapat dihindari lagi. Maka tantangan utama bagi dunia pendidikan saat ini adalah bagaimana menyelenggarakan pendidikan untuk membentuk sumber daya manusia yang profesional di masa global. Kualitas sumber daya manusia (SDM) memegang peranan penting dalam kondisi persaingan global yang penuh dengan tekanan dan kompetisi.

Menurut Nurdin (2001) Dalam menghasilkan sumber daya manusia yang cerdas dan terampil dalam menguasai ilmu pengetahuan, kebudayaan, politik, pertahanan, keamanan serta teknologi. Semua itu akan tercapai apabila generasi muda sekarang ini memiliki efikasi diri yang tinggi. Selanjutnya Suharman (2011) Menyatakan Kreativitas yang dimiliki seseorang akan menimbulkanefikasi diri, sedangkan efikasi diri akan menjadikan seseorang mampu hidup mandiri. Menurut Munandar (2012) Anak dan remaja kreatif biasanya cukup mandiri dan memiliki rasa percaya diri. Mereka lebih berani mengambil resiko (tetapi dengan perhitungan) dari pada anak pada umumnya. Anak yang kreatif yang tinggi disertai dengan rasa ingin tahu yang besar dan haus akan tantangan berfikir membuat seseorang gemar melakukan eksplorasi. Disamping itu kreatif juga memungkinkan manusia meningkatkan hidupnya. Sedangkan Menurut Zohar (2005) Menyatakan bahwa dalam membentuk sumber daya manusia yang professional, penuh percaya diri dan mandiri membutuhkan yang namanya kecerdasan spiritual karena pada dasarnya orang yang memiliki kecerdasan spiritual yang rendah akan mendatangkan kehancuran pada dirinya sendiri. Kaitannya dengan manusia yang berkualitas, mahasiswa adalah aset nasional yang diharapkan mampu menguasai suatu bidang sehingga keahliannya menjadi siap bersaing di pasaran kerja untuk mempertahankan eksistensi bangsa dan aktualisasi diri sesuai dengan bidang keahliannya.

Mahasiswa adalah peserta didik yang terdaftar dan belajar dalam perguruan tinggi. Mahasiswa diharapkan menjadi tulang punggung atau penerus guna menjadi tenaga profesional yang berkualitas sehingga mampu menerapkan keahliannya di tengah-tengah masyarakat yang semakin ketat dalam persaingan kerja.Fakultas Ekonomi UNIM (Universitas Islam Majapahit) terdapat dua bidang keilmuan yaituJurusan Akuntansi dan manajemen. Kedua jurusan tersebut memiliki tujuan, salah satunya yaitu menyiapkan peserta didik yang memiliki kemampuan profesional dibidang Manajemen yang berjiwa entrepreneur, dengan tujuan tersebut mahasiswa Fakultas Ekonomi UNIM diharapkan memiliki kemampuan adaptasi secara kreatif sehingga mampu melihat peluang-peluang yang ada, dengan kata lain diharapkan untuk menjadi kreatif.

Menurut Dekan Fakultas Ekonomi dan data kurikulum Fakultas Ekonomi UNIM Pada jurusan manajemen diadakan mata kuliah kewirausahaan sebagai mata kuliah pengembangan kepribadian sebanyak 2 SKS dengan tujuan untuk menumbuhkembangkan jiwa kewirausahaan yaitu kemampuan memotivasi diri agar mampu mengindera peluang usaha, menciptakan jasa produksi, pemasaran, kemitraan dan manajemen. Dengan harapan mahasiswa lebih kreatif karena mereka telah melihat kondisi secara langsung melalui kegiatan praktik tersebut. 
Mahasiswa jurusan Manajemen 2012 telah menempuh mata kuliah kewirausahaan tersebut, selain itu mahasiswa jurusan Manajemen 2012 telah mencapai tingkat akhir dalam menempuh kuliah S1 yaitu selama 4 tahun, dan dalam proses penyusunan sekripsi dan kemudian akan lulus, serta mahasiswa juga akan berangan-angan "apa yang harus aq lakukan setelah lulus kuliah nanti", namun dengan adanya materi mata kuliah dan praktik kewirausahaan bisa dijadikan mahasiswa jurusan manajemen sebagai dasar acuan dalam menemukan dan memanfaatkan peluang dimasa mendatang.

Berdasarkan hasil wawancara dengan Dekan Fakultas ekonomi sekaligus pengajar mata kuliah kewirausahaan menyatakan bahwa denga adanya mata kuliah kewirausahaan akan mampu meningkatkan kreativitas mahasiswa dan hal itu diharap mampu meningkatkan efikasi diri dan kemandirian pada mahasiswa angkatan 2012. Pada kompetensi dasar yang tercantum pada silabus mata kuliah kewirausahaan dimana mahasiswa diharapkan mampu membuat rancangan usaha (business plan), mahasiswa dilatih untuk merancang langkah bisnis kedepan dengan cara memunculkan ide/gagasan kreatif dengan cara membuat bisnis plan. Setelah mahasiswa memiliki ide yang kreatif yang dituangkan pada bisnis plan kemudian mampu mempraktekkan langsung apa yang telah dibuat dalam bisnis plan. Dari kegiatan tersebut yang dirasakan mahasiswa yaitu ketika sudah memiliki kreativitas yang bagus/unik akan termotivasi untuk mengembangkan atau melanjutkan gagasan kreativitas yang telah dimiliki.

Selain kreativitas yang sudah dimiliki mahasiswa, Menurut Zohar (2005) menyatakan bahwa untuk membentuk sumber daya manusia yang professional, penuh percaya diri dan mandiri membutuhkan yang namanya kecerdasan spiritual karena pada dasarnya orang yang memiliki kecerdasan spiritual yang rendah akan mendatangkan kehancuran pada dirinya sendirikecerdasan spritual menjadi faktor terpenting sehingga mampu meningkatkan kreativitas serta memunculkan ide-ide baru.

Berdasakan hasil wawancara dengan dosen mata kuliah agama islam kecerdasan spiritual mahasiswa mulai bertambah sesudah mendapat mata kuliah agama islam di simester 1, mata kuliah manajemen syariah dan ekonomi syariah di simester 3. Dengan adanya ketiga mata kuliah diatas dosen mata kuliah agama islam menyatakan bahwa tingkat efikasi diri dan kemandirian mahasiswa semakin bertambah dalam menyelesaikan permasalahan. Selain itu sesuai dengan kurikulum berkarakter yang sudah di terapkan, dosen yang selalu menyisipkan penjelasan bahwa sebagai mahasiswa yang baik harus selalu bertindak sesuai dengan norma-norma agama. Hal itulah yang menjadikan mahasiswa memiliki efikasi diri yang lebih tinggi danmenjadi pribadi yang mandiri sehingga lebih yakin akan mampu bersaing ketika sudah masuk kedunia kerja serta mampu berwirausaha sendiri.

Menurut O'Brien (2003) pengertian efikasi diri adalah keyakinan individu tentang kemampuan dirinya dalam melaksanakan tugas atau melakukan suatu tindakan yang diperlukan untuk mencapai suatu hasil tertentu. Menurut Geofrei (2000) salah satu ciri dan sifat wirausaha adalah percaya diri, sedangkan percaya diri adalah keyakinan, ketidakketergantungan, individualitas optimisme. Sedangkan menurut Bandura (2012) mengungkapkan perbedaan efikasi diri pada tiap individu tertelak pada tiga komponen, yaitu magnitude, strength, dan generality. 
Hasil Penelitian Garima (2012) menunjukkan bahwa kecerdasan Spiritual pengaruh terhadap efikasi diri dan kemandirianpada diri seseorang. Hasil penelitian Garima diperkuat dengan pendapat Zohar (2005) yang menyatakan bahwa kecerdasan spiritual membuat seseorang bisa mengkritisi apa yang ada dan apa yang mungkin akan terjadi, dan menjadikan orang tersebut membayangkan kemungkinan yang akan terjadi, hal itu yang merubah pola pikir sehingga merasa sanggup dan percaya diri dalam menyelesaikan problem dalam situasi apapun. Okpara (2007) juga menunjukkan bahwa nilai kreativitas sangat penting bagi kesuksesan seorang wirausaha. Anak dan remaja kreatif biasanya cukup mandiri dan memiliki rasa percaya diri. Seorang wirausaha lebih berani mengambil resiko (tetapi dengan perhitungan) dari pada anak pada umumnya. Anak yang kreatif yang tinggi disertai dengan rasa ingin tahu yang besar dan haus akan tantangan berfikir membuat seseorang gemar melakukan eksplorasi. Disamping itu kreatif juga memungkinkan manusia meningkatkan hidupnya.

Menurut Agung (2010) menyatakan bahwa kreativitas bukan merupakan bakat bawaan seseorang sejak dirinya dilahirkan di dunia ini, akan tetapi kretaivitas merupakan suatu hal yang dapat dipelajari dan dilakukan oleh siapa saja. Dari pernyataan di atas menunjukkan bahwa kreativitas mahasiswa UNIM bisa terbentuk dengan adanya mata kuliah kewirausahaan yang didapat pada simester empat. Adapun indikator pengukuran kreativitas yang digunakan dalam penelitian ini yaitu: 1) Dimensi kognitif, 2) Dimensi afektif, 3) Dimensi psikomotor. Mata kuliah kewirausahaan mengajarkan seseorang untuk menjadi pribadi yang kreatif, percaya diri dan mandiri yang mencerminkan sifat-sifat wirausaha. yang dimaksud percaya diri di sini adalah efikasi diri.dimana menurut John P (2002) efikasi diri merupakan keyakinan akan kemampuan diri dalam menguasai suatu situasi dan menghasilkan akhir yang diinginkan. Jadi dapat dikatakan ketika seseorang memiliki keyakinan pada dirinya maka seseorang tersebut akan berusaha sekuat tenaga untuk menghasilkan hasil akhir yang diinginkan. Adapun indikator pengukuran efikasi diri yang digunakan dalam penelitian iniyaitu: 1) Magnitude (tingkat kesulitan tugas), 2) Strength (kekuatan keyakinan), 3) Generality (generalitas).

Menurut Adegbola (2011) Kecerdasan spiritual dan efikasi diri keduanya telah diidentifikasi sebagai faktor yang berkontribusi terhadap pengelolaan kualitas hidup. Jadi secara tidak langsung kecerdasan spiritual memberi efek yang sangat besar bagi kehidupan serta efikasi diri pada diri kita. Menurut Menurut Zohar (2005) kecerdasan spiritual adalah kecerdasan jiwa, yaitu kecerdasan yang membuat kita menjadi utuh, serta membuat kita mengintegrasikan berbagai fragmen kehidupan, aktifitas dan keberadaan kita. Kecerdasan spiritual adalah kecerdasan yang kita pakai untuk merengkuh makna, nilai, tujuan terdalam dan motivasi tertinggi dalam proses berfikir kita untuk mengambil keputusan yang kita buat,dan dalam segala sesuatu yang patut dilakukan. Adapun indikator pengukuran kecerdasan spiritual yang digunakan dalam penelitian ini yaitu: Memiliki Kesadaran Diri, Memiliki Visi, Bersikap Fleksibel, Bepandangan Holistik, Melakukan Perubahan, Sumber Inspirasi, dan Refleksi Diri

Menurut Rogers dalam Suharnan (2011) menyatakan bahwa Orang kreatif selalu berusaha mencari sesuatu dan aktif membentuk lingkungan dari pada mengikuti arus dan kemauan lingkungan, ia akan membentuk pendapat sendiri tanpa tergantung pendapat orang lain. Dengan jata lain orang kreatif akan mampu 
berfikir mandiri dan mengambil keputusan sendiri tanpa adanya pengruh dari orang lain. Menurut Zimmerman (2002), kemandirian adalah sebuah konsep mengenai bagaimana individu menjadi regulator atau pengatur bagi dirinya sendiri. Adapun indikator pengukur kemandirian yang digunakan dalam penelitian ini yaitu: 1) Receivingatau menerima informasi yang relevan, 2) Evaluating atau mengevalusi informasi, 3) Searching atau mencari solusi, 4) Formulating atau merancang suatu rencana, 5) Implementing atau menerapkan rencana, 6) Assessing atau mengukur efektivitas dari rencana yang telah dibuat.

Mahasiswa cenderung mempunyai waktu yang cukup untuk belajar berbagai ilmu yang diperlukan serta meningkatkan kemampuan kecerdasan spiritual mereka sehingga peluang untuk maju dan sukses masih terbuka lebar dikarenakan sudah mendapatkan bekal kreativitas saat proses belajar mengajar. Oleh karena itu mahasiswa diharapkan untuk mengembangkan dan memanfaatkan ilmu pengetahuan serta teknologi guna dapat menambah efikasi diridan kemandirian mahasiswa.Seorang mahasiswa yang memiliki kreativitasdan kecerdasan spiritual maka mereka semakin yakin akan kemampuannya dan mandiri dalam menyelesaikan kesulitan tugas yang sedang dihadapi dengan kreativitas yang mereka miliki selain itu mereka juga akan selalu berupaya dengan gigih untuk mencapai tujuan yang ingin dicapai sehingga dengan kreativitas yang dimiliki mahasiswa akan semakin yakin dapat melakukan perubahan kepada dirinya maupun orang lain.

Berdasarkan hasil wawancara dengan 10 mahasiswa angatan 2012 jurusan Manajemen FE UNIM, didapat bahwa mahasiswa jurusan Manajemen 2012telah diarahkan untuk menjadi mahasiswa yang kreatif dalam proses pembelajaran mata kuliah kewirausahaan. Mahasiswa Jurusan Manajemen FE UNIM dengan mendapatkan kecerdasan spritual yang tinggidiharapmampu meningkatkan efikasi diri dan mandiri dengan kreativitas yang telah mereka miliki. Berdasarkan latar belakang tersebut Peneliti bermaksud meneliti adalah "Pengaruh Kreativitas dan kecerdasan Spiritual Terhadap Efikasi Diri dan Kemandirian Mahasiswa Jurusan Manajemen Fakultas Ekonomi UNIM Mojokerto".

Berdasarkan pemikiran dan kajian empiris diatas, maka penelitian difokuskan untuk menganalisis pengaruh kreativitas terhadap efikasi diri, kreativitas terhadap kemandirian, kecerdasan spiritual terhadap efikasi diri, kecerdasan spiritual terhadap kemandirian, efikasi diri terhadap kemandirian, kreativitas terhadap kemandirian melalui efikasi diri, dan kecerdasan spiritual terhadap kemandirian melalui efikasi diri.

\section{METODE PENELITIAN}

Pendekatan yang digunakan dalam penelitian ini adalah pendekatan kuantitatif. Berdasarkan rumusan masalah maka pendekatan yang tepat pada penelitian ini adalah pendekatan kuantitatif karena penelitian ini mencakup hal-hal yang didasarkan pada perhitungan persentase, perhitungan statistik, dan lain-lain. Dalam penelitian ini terdiri dari empat variabel, yang terdiri dari dua variabel bebas yaitu variabel kreativitas $\left(\mathrm{X}_{1}\right)$ dan kecerdasan spiritual $\left(\mathrm{X}_{2}\right)$, serta dua variabel terikat yaitu efikasi diri $\left(\mathrm{Y}_{1}\right)$ dan kemandirian $\left(\mathrm{Y}_{2}\right)$.

Dalam penelitian ini yang digunakan sebagai populasi adalah mahasiswa Manajemen UNIM angkatan 2012. Teknik pengambilan sampel yang akan 
digunakan adalah simple random sampling. Berdasarkan rumus teknik pengambilan sampel, dan presisi atau taraf kesalahan sebesar 1 persen, maka dapat diperoleh besaran sample sebesar 113 orang.

\section{HASIL DAN PEMBAHASAN}

Hasil pengujian hipotesis dilakukan setelah melalui serangkaian tahapan pengujian analisis SEM untuk mengetahui hubungan antar variabel endogen dan eksogen sesuai dengan hipotesis yang telah diajukan. Dalam penelitian ini penulis mengajukan (5) lima hipotesis, adapun hasil pengujian 10 hipotesis yang diajukan dan disajikan pada table 1 sebagai berikut:

Tabel 1

Hasil Pengujian Hipotesis

\begin{tabular}{|l|l|c|c|l|}
\hline No & Variabel & Koefisien & C.R. & Keterangan \\
\hline 1. & $\begin{array}{l}\text { kreativitas }\left(\mathrm{X}_{1}\right) \rightarrow \text { efikasi } \\
\text { diri }\left(\mathrm{Y}_{1}\right)\end{array}$ &, 537 & 3,023 & Signifikan \\
\hline 2 & $\begin{array}{l}\text { kreativitas }\left(\mathrm{X}_{1}\right) \rightarrow \\
\text { kemandirian }\left(\mathrm{Y}_{2}\right)\end{array}$ &, 320 & 2,023 & Signifikan \\
\hline 3 & $\begin{array}{l}\text { Kecerdasan spiritual }\left(\mathrm{X}_{2}\right) \rightarrow \\
\text { efikasi diri }\left(\mathrm{Y}_{1}\right)\end{array}$ &, 272 & 2,371 & Signifikan \\
\hline 4 & $\begin{array}{l}\text { Kecerdasan spiritual }\left(\mathrm{X}_{2}\right) \rightarrow \\
\text { kemandirian }\left(\mathrm{Y}_{2}\right)\end{array}$ &, 141 & 1,008 & Tidak Signifikan \\
\hline 5 & $\begin{array}{l}\text { efikasi diri }\left(\mathrm{Y}_{1}\right) \rightarrow \\
\text { kemandirian }\left(\mathrm{Y}_{2}\right)\end{array}$ &, 479 & 3,404 & Signifikan \\
\hline
\end{tabular}

Sumber : Data diolah (2014)

Hipotesis pertama $\left(\mathrm{H}_{1}\right)$ menyatakan bahwa kreativitas berpengaruh terhadap efikasi diri. Koefisien jalur yang bertanda positif sebesar 0,537 dengan nilai C.R. sebesar 3,023 lebih besar dari 1,96, artinya kretivitas mahasiswa berpengaruh terhadap efikasi diri. Jadi hipotesis pertama $\left(\mathrm{H}_{1}\right)$ yang menyatakan bahwa kreativitas berpengaruh terhadap efikasi diri diterima.

Hipotesis ke-dua $\left(\mathrm{H}_{2}\right)$ menyatakan bahwa kretivitas berpengaruh terhadap kemandirian. Koefisien jalur yang bertanda positif sebesar 0,320 dengan nilai C.R. sebesar 2,023 lebih besar dari 1,96, artinya kretivitas mahasiswa berpengaruh terhadap kemandirian. Jadi hipotesis ke-dua $\left(\mathrm{H}_{2}\right)$ yang menyatakan bahwa kretivitas berpengaruh terhadap kemandirian diterima.

Hipotesis ke-tiga $\left(\mathrm{H}_{3}\right)$ menyatakan bahwa kecerdasan spiritual berpengaruh terhadap efikasi diri. Koefisien jalur yang bertanda positif sebesar 0,272 dengan nilai C.R. sebesar 2,371 lebih besar dari 1,96, artinya kecerdasan spiritual mahasiswa berpengaruh terhadap efikasi diri. Jadi hipotesis ke-tiga (H3) yang menyatakan bahwa kecerdasan spiritual berpengaruh terhadap efikasi diri diterima.

Hipotesis ke-empat $\left(\mathrm{H}_{4}\right)$ menyatakan bahwa kecerdasan spiritual berpengaruh terhadap kemandirian. Koefisien jalur yang bertanda positif sebesar 0,141 dengan nilai C.R sebesar 1,008 lebih kecil dari 1,96, artinya kecerdasan spiritual mahasiswa berpengaruh terhadap kemandirian. Jadi hipotesis ke-empat $\left(\mathrm{H}_{4}\right)$ yang menyatakan bahwa kecerdasan spiritual berpengaruh terhadap kemandirian diri ditolak. 
Hipotesis ke-lima $\left(\mathrm{H}_{5}\right)$ menyatakan bahwa efikasi diri berpengaruh terhadap kemandirian. Koefisien jalur yang bertanda positif sebesar 0,479dengan nilai C.R. sebesar 3,404 lebih besar dari 1,96, artinya kretivitas mahasiswa berpengaruh terhadap efikasi diri. Jadi hipotesis ke-lima $\left(\mathrm{H}_{5}\right)$ yang menyatakan bahwa efikasi diri berpengaruh terhadap kemandirian.

Pengujian pengaruh kreativitas terhadap kemandirian melalui efikasi diri dan pengaruh kecerdasan spiritual terhadap kemandirian melalui efikasi diri akan diperjelas pada poin a dan b di bawah ini: Hipotesis ke-enam $\left(\mathrm{H}_{6}\right)$ pengaruh tidak langsung kreativitas terhadap kemandirian melalui efikasi diri

Tabel 2

Pengaruh tidak langsung kreativitas terhadap kemandirian melalui efikasi diri

\begin{tabular}{|l|c|c|c|c|}
\hline \multicolumn{1}{|c|}{ Jalur } & Koefisien & $\begin{array}{c}\text { Std } \\
\text { error }\end{array}$ & $\begin{array}{c}\text { t hitung } \\
(\mathbf{C R})\end{array}$ & ketrangan \\
\hline $\begin{array}{l}\text { kreativitas }\left(\mathrm{X}_{1}\right) \rightarrow \\
\text { efikasi diri }\left(\mathrm{Y}_{1}\right)\end{array}$ & 0,481 & 0,159 & 3,034 & signifikan \\
\hline $\begin{array}{l}\text { efikasi diri }\left(\mathrm{Y}_{1}\right) \rightarrow \\
\text { kemandirian }\left(\mathrm{Y}_{2}\right)\end{array}$ & 0,687 & 0,218 & 3,159 & signifikan \\
\hline $\begin{array}{l}\text { kreativitas }\left(\mathrm{X}_{1}\right) \rightarrow \\
\text { kemandirian }\left(\mathrm{Y}_{2}\right)\end{array}$ & 0,479 & 0,203 & 2,365 & signifikan \\
\hline Kan & & &
\end{tabular}

Koefisien tidak langsung : kreativitas $\left(\mathrm{X}_{1}\right) \rightarrow$ efikasi diri $\left(\mathrm{Y}_{1}\right) \rightarrow \operatorname{kemandirian}\left(\mathrm{Y}_{2}\right)$ : $0,481 \times 0,687=0,330$

Sumber : Data diolah (2014)

Untuk menghitung t hitung pengaruh tidak langsung dapat dilakukan dengan uji Sobel menurut Hayes (2013) dengan rumus sebagai berikut. Hasil t hitung koefisien tidak langsung sebesar $0,331<$ nilai $\mathrm{Z}$ test $(1,96)$. Hal ini menunjukkan bahwa pengaruh kreativitas $\left(\mathrm{X}_{1}\right)$ terhadap kemandirian $\left(\mathrm{Y}_{2}\right)$ melalui efikasi diri $\left(\mathrm{Y}_{1}\right)$ sebesar 0,330 tidak signifikan. Sehingga, berdasarkan perhitungan di atas, hipotesis enam $\left(\mathrm{H}_{6}\right)$ yang menyatakan efikasi diri memediasi krativitas terhadap kemandirian mahasiswa ditolak. Hipotesis tujuh $\left(\mathrm{H}_{7}\right)$ pengaruh tidak langsung kecerdasan spiritual terhadap kemandirian melalui efikasi diri.

Untuk menghitung t hitung pengaruh tidak langsung dapat dilakukan dengan uji Sobel menurut Hayes (2013) dengan rumus sebagai berikut: Hasil t hitung koefisien tidak langsung sebesar $0,233<$ nilai $\mathrm{Z}$ test $(1,96)$ menunjukkan bahwa koefisien tidak langsung jalur kecerdasan spiritual $\left(\mathrm{X}_{2}\right) \rightarrow$ efikasi diri $\left(\mathrm{Y}_{1}\right) \rightarrow$ kemandirian $\left(\mathrm{Y}_{2}\right)$ sebesar 0,233tidak signifikan. Sehingga, berdasarkan perhitungan di atas hipotesis tujuh $\left(\mathrm{H}_{7}\right)$ yang menyatakan efikasi diri memediasi kecerdasan spiritual terhadap kemandirian mahasiswa ditolak.

Berdasarkan hasil pengujian hipotesis pertama dengan menggunakan analisis persamaan model struktural menunjukkan bahwa kreativitas mempunyai pengaruh yang signifikan terhadap efikasi diri mahasiswa. Hasil tersebut dapat dilihat dari nilai koefisien jalur kreativitas $\left(\mathrm{X}_{1}\right)$ terhadap efikasi diri $\left(\mathrm{Y}_{2}\right)$ sebesar 0,533, artinya jika kreativitas naik maka efikasi diri mahasiswa akan naik sebesar 0,355 dengan nilai Critical Ratio sebesar 3,023 > 1,96. Hal ini berarti semakin meningkat kreativitas mahasiwa jurusan manajemen Fakultas Ekonomi UNIM (Universitas Islam Majapahit) maka akan semakin baik pula tingkat efikasi mahasiswa dalam berwirausahanya. Hasil penelitian ini mendukung pernyataan Suharman (2011) yang menyatakan bahwa kreativitas yang dimiliki seseorang 
akan menimbulkan efikasi diri, sedangkan efikasi diri akan menjadikan seseorang mampu hidup mandiri.

Tabel 3

Pengaruh Tidak Langsung kecerdasan spiritual Terhadap kemandirian dimediasi oleh efikasi diri

\begin{tabular}{|c|c|c|c|c|}
\hline Jalur & Koefisien & Std error & $\begin{array}{l}\text { t hitung } \\
\text { (CR) }\end{array}$ & Keterangan \\
\hline $\begin{array}{l}\text { Kecerdasan spiritual }\left(\mathrm{X}_{2}\right) \\
\rightarrow \text { efikasi diri }\left(\mathrm{Y}_{1}\right)\end{array}$ & 0,323 & 0,172 & 2,284 & signifikan \\
\hline $\begin{array}{l}\text { Efikasi diri }\left(\mathrm{Y}_{1}\right) \rightarrow \\
\text { kmandirian }\left(\mathrm{Y}_{2}\right)\end{array}$ & 0,687 & 0,218 & 3,159 & Signifikan \\
\hline $\begin{array}{l}\text { Kecerasan spiritual }\left(\mathrm{X}_{2}\right) \\
\rightarrow \text { kemanirian }\left(\mathrm{Y}_{2}\right)\end{array}$ & 0,005 & 0,192 & 0,026 & $\begin{array}{c}\text { Tidak } \\
\text { signifikan }\end{array}$ \\
\hline
\end{tabular}

Koefisien tidak langsung : kecerdasan spiritual $\left(\mathrm{X}_{2}\right) \rightarrow$ efikasi diri

$\left(\mathrm{Y}_{1}\right) \rightarrow$ kemandirian $\left(\mathrm{Y}_{2}\right): 0,323 \times 0,687=0,222$

Sumber : Data diolah (2014).

Selain itu hasil penelitian ini mendukung hasil penelitian sebelumnya yang dilakukan oleh Tan (2011) yang menyatakan bahwa kreativitas merupaka modal penting bagi seorang karyawan untuk memiliki rasa efikasi diri ketika mau melakuka segala macam pekerjaan. Dalam penelitian yang dilakukan Tan disimpulkan bahwa keberhasilan pekerjaan itu akan bisa dicapai oleh orang yang kreatif. Selain itu penelitian yang dilakukan Andrea (2008) menunjukkan bahwa efek kretaifitas yang dimiliki seseorang akan menjadikan orang tersebut semakin tinggi efikasi dirnya serta bisa meningkatkan karier mereka. Semua hasil penelitian diatas diperkuat berdasarkan pendapat Munandar (2012) Anak dan remaja kreatif biasanya cukup mandiri dan memiliki rasa percaya diri. Mereka lebih berani mengambil resiko (tetapi dengan perhitungan) dari pada anak pada umumnya. Anak yang kreatif yang tinggi disertai dengan rasa ingin tahu yang besar dan haus akan tantangan berfikir membuat seseorang gemar melakukan eksplorasi. Disamping itu kreatif juga memungkinkan manusia meningkatkan kualitas hidupnya.

Kreativitas berpengaruh signifikan terhadap efikasi diri mahasiwa jurusan manajemen Fakultas Ekonomi UNIM didukung oleh temuan pada variabel kretifitas dalam penelitian ini lebih dominan di dukung oleh indikator dimensi afektif yaitu merupakan tanggapan responden dengan nilai rata-rata atertinggi 4,186 dengan kategori tinggi. Hal ini menunjukkan bahwan mahasiwa jurusan manajemen Fakultas Ekonomi UNIM benar-benar memiliki rasa ingin tahu, suka berimajenasi, berani menanggung resiko serta benar-benar suka tantangan. Semua pernyataan tadi dapat terbukti dengan data yang diperoleh dari deskripsi responden yang menunjukkan bahwa jumlah mahasiswa yang sudah berwirausaha lebih banyak yaitu 63\% sedangkan yang belum pernah sebanyak 37\%. Dengan demikian dapat disimpulkan bahwa kreativitas memberi sumbangan yang positif terhadap efikasi diri mahasiwa jurusan manajemen Fakultas Ekonomi UNIM. Demikian hipotesis yang menyatakan diduga ada pengaruh signifikan kreativitas terhadap efikasi diri pada mahasiswa jurusan manajemen Fakultas Ekonomi UNIM dapat diterima. 
Berdasarkan hasil pengujian hipotesis dua dengan menggunakan analisis persamaan model struktural menunjukkan bahwa kreativitas mempunyai pengaruh yang signifikan terhadap kemandirian mahasiswa. Hasil tersebut dapat dilihat 0 , 320, artinya jika kreativitas naik maka efikasi diri mahasiswa akan naik sebesar 0,320 dengan nilai Critical Ratio sebesar 2,032 > 1,96. Hal ini berarti semakin meningkat kretifitas mahasiwa jurusan manajemen Fakultas Ekonomi UNIM maka akan semakin baik pula tingkat kemandirian mahasiswa dalam berwirausahanya.. Hasil penelitian ini mendukung pernyataan Ward (2003) bahwa kreativitas mampu menghasilkan ide-ide baru dan berguna untuk usaha bisnis. Perhatian diberikan kepada yang dapat meningkatkan kreativitas, pengetahuan karena mempengaruhi orisinalitas ide baru yang dihasilkan.

Kreativitas dalam dimensi psikomotorik berkaitan dengan kemungkinan atau kecenderungan bahwa seseorang akan melakukan tidakan tertentu yang berkaitan dengan objek, seperti membuat cara yang unik untuk menemukan jalan keluar (Munandar, 2012). Hal ini ditunujukkan oleh tanggapan mahasiswa jurusan manajemen Fakultas Ekonomi UNIM bahwa mereka mampu mampu menemukan jalan keluar dalam setiap masalah yang dihadapi, mampu membuat sesuatu yang unik setelah mendapatkan mata kuliah kewirausahaan dan mampu menemukan peluang di masa depan. Kemampuan kreatif dalam dimensi psikomotorik harus disertai dengan kemandiran untuk selalu terbuka menerima informasi dari manapun asalkan yang relevan, selalu mengevalusi informasi bermanfaat atau tidak bagi diri sendiri dan selalu mencari solusi untuk setiap permasalahan yang ada. Hal itu diterapkan mahasiswa jurusan manajemen Fakultas Ekonomi UNIM dengan membuka wirausaha baru walapun dengan modal yang tidak terlalu besar.

Kreativitas dan kemandirian sangat penting dalam proses pembelajaran, karena pertama, kreativitas memberikan peluang bagi mahasiswa jurusan manajemen Fakultas Ekonomi UNIM untuk mengaktualisasikan dirinya, kemudian kreativitas memungkinkan mahasiswa menemukan berbagai alternatif dalam pemecahan masalah, kreativitas membuka jalan berfikir mahasiswa sehingga lebih inovatif dan menghasilkan output yang lebih baik, dan kreativitas juga dapat meningkatkan prestasi mahasiswa dalam proses pembelajaran. Dari segi afektifnya, kreativitas ditandai dengan motivasi yang kuat, rasa ingin tahu, tertarik dengan tugas majemuk, berani menghadapi resiko, tidak mudah putus asa, menghargai keindahan, memiliki rasa humor, selalu ingin mencari pengalaman baru, menghargai diri sendiri dan orang lain, dan sebagainya. Kemudian kemandirian juga sangat diperlukan dalam proses pembelajaran, karena kemandirian merupakan kunci utama bagi individu untuk mampu mengarahkan dirinya kearah dan tujuan dalam kehidupannya. Kemandirian didukung dengan kualitas pribadi yang ditandai dengan penguasaan kompetensi tertentu, konsistensi terhadap pendiriannya, kreatif dalam berfikir dan bertindak, mampu mengendalikan dirinya dan memiliki komitmen yang kuat dalam berbagai hal. Ketika kreativitas dan kemandirian dimiliki mahasiswa jurusan manajemen Fakultas Ekonomi UNIM, maka proses pembelajaran akan lebih optimal. Demikian hipotesis yang menyatakan diduga ada pengaruh signifikan kretifitas terhadap kemandirian pada mahasiwa jurusan manajemen Fakultas Ekonomi UNIM dapat diterima.

Berdasarkan hasil pengujian hipotesis satu engan menggunakan analisis persamaan model struktural menunjukkan bahwa kreativitas mempunyai pengaruh 
yang signifikan terhadap efikasi diri mahasiswa. Hasil tersebut dapat dilihat dari nilai koefisien jalur Kecerdasan Spiritual $\left(\mathrm{X}_{2}\right)$ terhadap efikasi diri $\left(\mathrm{Y}_{2}\right)$ sebesar 0,272, artinya jika krreatifitas naik maka efikasi diri mahasiswa akan naik sebesar 0,272 dengan nilai Critical Ratio sebesar 2,371>1,96. Hal ini berarti semakin meningkat Efikasi Diri mahasiswa jurusan manajemen Fakultas Ekonomi UNIM maka akan semakin baik pula tingkat efikasi diri mahasiswa dalam berwirausahanya. Hasil penelitian ini mendukung pernyataan Adegbola, Maxine (2011) bahwa spiritualitas dan self-efficacy keduanya telah diidentifikasi sebagai faktor yang berkontribusi terhadap eficasi diri seseorang untuk bisa sembuh dan memiliki kualitas hidup.

Kecerdasan spiritual lebih berkaitan dengan pencerahan jiwa. Orang yang memiliki kecerdasan spiritual tinggi mampu memaknai hidup dengan memberi makna positif pada setiap peristiwa, masalah, bahkan penderitaan yang dialaminya (Miller, 2002). Karena itu melalui kecerdasan spiritual, mahasiswa dapat melakukan pemberian makna yang positif dan mampu membangkitkan jiwa dan melakukan perbuatan dan tindakan yang positif dan selalu percaya diri dalam menghadapi segala sesuatu. Kecerdasan spritual mahasiswa dapat ditunjukkan oleh sifat tidak mudah putus asa terhadap setiap masalah dan mampu menerima perubahan menjadi lebih baik. Hal inilah yang akan dapat meningkatkan efikasi diri yaitu keyanikan akan mendapatkan apa yang dinginkan asalkan disertai usaha.

Mahasiswa mahasiwa jurusan manajemen Fakultas Ekonomi UNIM yang memiliki kecerdasan spiritual tinggi akan tekun dan berusaha mencari solusi saat menghadapi kesulitan. Mereka mampu menyemangati maupun memotivasi diri sendiri bahwa dirinya mampu melakukan pekerjaan dan tugas akademik. Selain itu, mereka mampu berfikir positif kepada diri sendiri seperti yakin terhadap kemampuan diri serta tidak mudah putus asa saat dihadapkan pada tugas yang sulit. Di samping itu, mereka juga mampu mengelola emosi serta menyadari emosi yang sedang dirasakan kemudian mengetahui cara mengatasinya sehingga tidak menganggu aktifitas ataupun tidak menganggu kosentrasi belajar.

Individu yang memiliki kecerdasan spiritual tinggi juga mampu menangani emosi sendiri agar berdampak positif bagi pelaksanaan tugas, peka terhadap kata hatidan sanggup menunda kenikmatan sebelum tercapainya tujuan. Ketika mengalami kegagalan, individu mampu bertahan dan tidak frustrasi, serta mampu menetralisirtekanan emosi. Hal-hal tersebut merupakan cerminan perilaku dari efikasi diri akademik. Sebagian besar mahasiswa jurusan manajemen Fakultas Ekonomi UNIM memiliki kecerdasan spiritual yang tinggi hal itu dapat ditunjukkan berdasarkan jawaban dari pertanyaan angket terbuka yang persentasenya rata-rata diatas $50 \%$. Hal ini sesuai dengan pendapat Bandura (1997) yang menyatakan bahwa efikasi diri seseorang salah satunya dipengaruhi oleh kondisi emosional. Ketika efikasi diri akademik tinggi maka akan menunjukkan ciri akan menghindari situasi yang menekan dan mengancam, seperti emosi, kegelisahan,dan sebagainya. Bandura (1997) menyebutkan bahwa ketika seseorang memilikiefikasi diri yang tinggi maka pantang menyerah, ulet, bersemangat, dan lain sebagainya. Demikian hipotesis yang menyatakan diduga ada pengaruh signifikan kecerdasan spiritual terhadap efikasi diri pada mahasiwa jurusan manajemen Fakultas Ekonomi UNIM dapat diterima.

Berdasarkan hasil pengujian hipotesis satu dengan menggunakan analisis persamaan model struktural menunjukkan bahwa kecerdasan spiritual mempunyai 
pengaruh yang signifikan terhadap kemandirian mahasiswa. Hasil tersebut dapat dilihat dari nilai koefisien jalur kecerdasan spiritual $\left(\mathrm{X}_{2}\right)$ terhadap kemandirian $\left(\mathrm{Y}_{2}\right)$ sebesar 0,141 , artinya jika kecerdasan spiritual naik maka kemandirian mahasiswa akan naik sebesar 0,141dengan nilai Critical Ratio sebesar 1,008 < 1,96. Hal ini berarti semakin meningkat kecerdasan mahasiwa jurusan manajemen Fakultas Ekonomi UNIM maka akan semakin baik pula tingkat kemandirian mahasiswa dalam berwirausahanya. Berdasarkan hasil analisis persamaan model struktural dapat diketahui bahwa pengaruh kecerdasan spiritual terhadap kemandirian tidak signifikan. Pernyataan diatas dapat dilihat berdasarkan nilai Critical Ratio yang tidak lebih besar dari 1,96. Hasil penelitian ini tidak mendukung pernyataan Eslami, Maryam Farsani (2013) bahwa kecerdasan spiritual mampu meningkatkan kepribadian perilaku seseorang untuk lebih baik.

Kecerdasan spiritual mahasiswa salah satunya adalah diperoleh dari kegiatan keagamaan yang diperoleh dikampus, hal itu akan menjadikan mahasiwa jurusan manajemen Fakultas Ekonomi UNIM memiliki ide cemerlang, namun ide yang cemerlang ini tidak diikuti dengan kemandirian berupa membuat planning yang matang untuk mencapai tujuan. Tanpa adanya perencanaan, mahasiwa jurusan manajemen Fakultas Ekonomi UNIM tidak dapat melakukan tindakan apapun yang akan di kerjakan dalam suatu kegiatan atau pekerjaan yang akan dijalankan, baik menentukan seperti apa kegiatannya, siapa yang berperan dalam kegiatan itu, dimana lokasi kegiatannya, kapan kegiatan akan dilaksanakan, mengapa kita mau melakukan kegiatan tersebut dan bagaimanakah proses kelangsungan kegiatan tersebut. Walaupun berdasarkan hasil jawaban tehadap pertanyaan angket terbukan menunjukkan persentase yang cukup tinggi akan tetapi hasilnya menunjukkan bahwa kecerdasan spiritual tidak berpengaruh terhadap kemandirian karena menurut manajemen Fakultas Ekonomi UNIM seorang harus memiliki kreatifitas dan melakukan tidakan atau berusaha sebagai pendukungnya yaitu meningkatkan kecerdasan spiritual, dengan begitu dianggap lebih baik dan mendapatkan hasil yang maksimal. Demikian hipotesis yang menyatakan diduga ada pengaruh signifikan kecerdasn spiritual terhadap kemandirian pada mahasiwa jurusan manajemen Fakultas Ekonomi UNIM dapat tidak diterima.

Berdasarkan hasil pengujian hipotesis satu dengan menggunakan analisis persamaan model struktural menunjukkan bahwa efikasi diri mempunyai pengaruh yang signifikan terhadap kemandirian mahasiswa. Hasil tersebut dapat dilihat dari nilai koefisien jalur efikasi diri $\left(\mathrm{Y}_{1}\right)$ terhadap kemandirian $\left(\mathrm{Y}_{2}\right)$ sebesar 0,479 artinya jika efikasi diri naik maka kemandirian mahasiswa akan naik sebesar 0,479 dengan nilai Critical Ratio sebesar 3,404>1,96. Hal ini berarti semakin meningkat efikasi diri mahasiwa jurusan manajemen Fakultas Ekonomi UNIM maka akan semakin baik pula tingkat kemandirian mahasiswa dalam berwirausahanya. Berdasarkan hasil analisis persamaan model struktural dapat diketahui bahwa ada pengaruh efikasi diri terhadap kemandirian. Hasil penelitian inimendukung penelitan Bryant, patter (2009) bahwa efikasi diri harus dimiliki oleh wirausaha agar memiliki kesadaran moral untuk menjaga agar tidak terjadi kegagalan dan kerugian dalam berwirausaha.

Mahasiswa efikasi diri mahasiwa jurusan manajemen Fakultas Ekonomi UNIM yang memiliki efikasi diri tinggi akan selalu lebih kreatif karena merupakan sesuatu yang bermanfaat dan berencana untuk berwirausaha setelah 
lulus kuliah. Hal ini karena dalam dirinya terdapat keyakinan seperti yang dinyatakan oleh Adegbola (2011), bahwa efikasi diriadalah keyakinan dalam kemampuan seseorang untuk melaksanakan suatu tindakan untuk tugas yang diperlukan berkaitan dengan hari ke hari gejala dan manajemen diri. Keyakinan mahasiswa tentang kemampuan dirinya dalam melaksanakan tugas atau melakukan suatu tindakan yang diperlukan untuk mencapai suatu hasil tertentu. Keyakinan inilah yang akan meningkatkan perilaku mandiri mahasiswa efikasi diri mahasiwa jurusan manajemen Fakultas Ekonomi UNIM dengan pengaturan diri dengan mengamati, mempertimbangkan, memberi ganjaran atau hukuman terhadap perilakunya sendiri.

Melalui kemandirian dan efikasi diri mahasiwa mahasiswa efikasi diri mahasiwa jurusan manajemen Fakultas Ekonomi UNIM melakukan kegiatan wirausaha atas dorongan diri sendiri untuk kebutuhan sendiri, mengejar prestasi, penuhketekunan, serta berkeinginan untuk melakukan sesuatu tanpa bantuan oranglain, mampu berpikir dan bertindak original, kreatif dan penuh inisiatif, mampu mempengaruhi lingkungannya, mempunyai rasa percaya diri terhadap kemampuan diri sendiri, menghargai keadaan diri sendiri, dan memperoleh kepuasan dari usahanya. Demikian hipotesis yang menyatakan diduga ada pengaruh signifikan efikasi diri terhadap kemandirian pada mahasiwa jurusan manajemen Fakultas Ekonomi UNIM dapat diterima.

Berdasarkan pengujian dengan uji Sobel diperoleh hasil yang menunjukkan bahwa efikasi diri tidak terbukti memediasi kreativitas terhadap kemandirian. Hasil tersebut dapat dilihat dari nilai $\mathrm{t}$ hitung koefisien tidak langsung sebesar $0,331<$ nilai $\mathrm{Z}$ test $(1,96)$ menunjukkan bahwa pengaruh kreativitas $\left(\mathrm{X}_{1}\right)$ terhadap kemandirian $\left(\mathrm{Y}_{2}\right)$ melalui efikasi diri $\left(\mathrm{Y}_{2}\right)$ sebesar 0,331 tidak signifikan. Hasil penelitian ini bertentangan dengan pernyataan Suharman (2011) yang menyatakan kreativitas yang dimiliki seseorang akan menimbulkan efikasi diri, sedangkan efikasi diri akan menjadikan seseorang mampu hidup mandiri.

Efikasi diri tidak terbukti memediasi kreativitas terhadap kemandirian mahasiswa jurusan manajemen Fakultas Ekonomi UNIM. Temuan dalam penelitian ini didukung oleh indikator pada variabel efikasi diri yang memiliki rata-rata sumbangan terendah yaitu pada indikator pertama yaitu magnitude. Hal ni menunjukkan dari hasil temuan bahwa mahasiswa memiliki keyakinan diri akan mampu memasuki peluang usaha dikarenankan mahasiswa sudah mendapatkan dua keilmuan yaitu pendidikan dan non kependidikan seperti mata kuliah kewirausahaan serta pengalaman-pengalaman yang telah didapat selama menapatkan tugas tentang kewirausahaan. Selain itu mahasiswa juga yakin dan mampu merealisasikan kreativitas yang dimiliki sehingga menghasilkan perubahan pada dirinya sendiri dan orang lain.

Kreativitas mendapat sumbangan terendah dari indikator kedua yaitu dimensi afektif. Hal ini dapat ditunjukkan dari hasil temuan walaupun banyak mahasiswa yang mualai berwirausaha sejak mereka masih duduk dibangku kulaiah akan tetapi tidak semua mahasiswa berani mengambil resiko untuk menjadi wirausaha muda yang memiliki imajenas tinggi serta suka tantangan

Berdasarkan hasil penelitian dijelaskan bahwa untuk mencapai tingkat kemandirian yang tinggi tidak perlu melalui mediator efikasi diri. Oleh karena itu, lebih baik langsung dari peningkatan variabel kreativitas. Sehingga, pendapat 
Suharman (2011) tidak terbukti. Efikasi diri ternyata tidak terbukti memediasikreativitas terhadap kemandirian mahasiswa jurusan manajemen Fakultas Ekonomi UNIM.

Berdasarkan pengujian dengan uji Sobel diperoleh hasil yang menunjukkan bahwa efikasi diri tidak terbukti memediasi kecerdasan spiritual terhadap kemandirian. Hasil tersebut dapat dilihat dari nilai t hitung koefisien tidak langsung sebesar $0,233<$ nilai $\mathrm{Z}$ test $(1,96)$ menunjukkan bahwa pengaruh kreativitas $\left(\mathrm{X}_{1}\right)$ terhadap kemandirian $\left(\mathrm{Y}_{2}\right)$ melalui efikasi diri $\left(\mathrm{Y}_{2}\right)$ sebesar 0,233 tidak signifikan. Hasil penelitian ini bertetangan dengan hasil penelitian yang dilakukan Yulia (2010) Achievement Motivation Training dengan pendekatan spiritual terbukti efektif untuk meningkatkan efikasi diri mahasiswa, sedangkan menurut, Suharman (2011) efikasi diri akan meningatkan kemandirian.

Efikasi diri tidak terbukti memediasi kecerdasan spiritual terhadap kemandirian mahasiswa jurusan manajemen Fakultas Ekonomi UNIM (Universitas Islam Majapahit). Temuan dalam penelitian ini didukung oleh indikator pada variabel efikasi diri yang memiliki rata-rata sumbangan terendah yaitu pada indikator pertama yaitu magnitude. Hal ni menunjukkan dari hasil temuan bahwa mahasiswa memiliki keyakinan diri akan mampu memasuki peluang usaha dikarenankan mahasiswa sudah mendapatkan dua keilmuan yaitu pendidikan dan non kependidikan seperti mata kuliah agama islam serta pengalaman-pengalaman yang telah didapat selama mendapatkan tugas tentang kewirausahaan semakin maksimal dengan meningkatnya kecerdasan spiritual mereka. Selain itu mahasiswa juga yakin dan mampu merealisasikan kecerdasan spiritual yang dimiliki baik yang berasal dari adanya mata kulaih agama islam dan aktifitas spiritual yang lain yang basa dilakukan rumah sehingga menghasilkan perubahan pada dirinya sendiri dan orang lain.

Kecerdasan spiritual mendapat sumbangan terendah dari indikator kedua dan ketiga yaitu memiliki visi dan bersikap fleksibel. Hal ini dapat ditunjukkan dari hasil temuan walaupun banyak mahasiswa jurusan manajemen Fakultas Ekonomi UNIM yang sudah memulai berwirausaha sejak mereka masih duduk dibangku kuliah akan tetapi mereka belum mampu menentukan visi wirausaha yang dijalani saat iniserta belum mampu bersikap fleksibel atau mampu menyesuikan diri dengan masyarakat agar supaya mampu mengidentifikasi apa yang dibutuhkan masayarakat saat ini.

Berdasarkan hasil penelitian dijelaskan bahwa kecerdasan spiritual untuk mencapai tingkat kemandirian yang tinggi tidak perlu melalui mediator efikasi diri. Oleh karena itu, lebih baik langsung dari peningkatan variabel kecerdasan spiritual. Sehingga, pendapat Yulia (2010) dan Suharman (2011) tidak terbukti. Efikasi diri ternyata tidak terbukti memediasi kecerdasan spiritual terhadap kemandirian mahasiswa jurusan manajemen Fakultas Ekonomi UNIM.

\section{SIMPULAN}

Berdasarkan hasil analisis dan pembahasaan, penelitian ini dapat disimpulkan sebagai berikut: Hasil pengujian menunjukkan bahwa kreativitas berpengaruh signifikan terhadap efikasi diri mahasiswa jurusan manajemen Fakultas Ekonomi UNIM. Hasil pengujian menunjukkan bahwa kreativitas berpengaruh terhadap kemandirian mahasiswa jurusan manajemen Fakultas 
Ekonomi UNIM. Hasil pengujian menunjukkan bahwa kecerdasan spiritual berpengaruh terhadap efikasi diri mahasiswa jurusan manajemen Fakultas Ekonomi UNIM. Hasil pengujian menunjukkan bahwa Kecerdasan spiritual tidak berpengaruh terhadap kemandirian mahasiswa jurusan manajemen Fakultas Ekonomi UNIM. Hasil pengujian menunjukkan bahwa efikasi diri berpengaruh terhadap kemandirian mahasiswa jurusan manajemen Fakultas Ekonomi UNIM. Hasil pengujian menunjukkan bahwa kreativitas tidak berpengaruh terhadap kemandirian melalui efikasi diri mahasiswa jurusan manajemen Fakultas Ekonomi UNIM (Universitas Islam Majapahit). Hasil pengujian menunjukkan bahwa kecerdasan spiritual tidak berpengaruh terhadap kemandirian melalui efikasi diri. Mahasiswa jurusan manajemen Fakultas Ekonomi UNIM.

\section{DAFTAR RUJUKAN}

Adegbola, Maxine, 2011. "Spirituality, Self-Efficacy, and Quality of Life among Adults with Sickle Cell Disease" Published in final edited form as: South Online J Nurs Res. April: vol 11 no 1 summer 2011

Agung, Iskandar, 2010. Meningkatkan kreativitas pembelajaran bagi guru. Jakarta: PT. Bestari Buana Murni

Alwisol, 2004. Psikologi Kepribadian. Malang: UMM press

Andrea E. Abele \& Daniel Spurk, 2008. The longitudinal impact of self-efficacy and career goals on objective and subjective career success. Journal of Vocational Behavior Social Psychology Group, University of ErlangenNuremberg. Vol 74 summer 2009 pp 53-62

Tan, Ai-Girl \& Joe Li. 2011. Creativity Self-Efficacy Scale as a Predictor for Classroom Behavior in a Chinese Student Context. The Open Education Journal. Vol 8 no 14, 2011 pp 90-94

Bandura, A., 2006. Self-Efficacy: The exercise of control. New York: W. H. Freeman.

Eslami, Maryam Farsani, 2013. The study of relationship between spiritual intelligence with personality traits among physical education managers in Isfahan province. Vol 4 no 4. Summer 2013 pp 140144

Garima, Mrs Gupta, 2012. Spiritual intelegence, and emotional intelegence to self efficacy and self regulation among college students. International Journal Of Social Sciences \& Interdisciplinary Research. Vol.1 No. 2, summer 2012

Geoffrey G. \& Meredith, 2000. Kewirausahaan Teori dan Praktek. Jakarta: CV.Taruna Grafica

Hayes, Andrew F., 2013 "Introduction to mediation, moderation and conditional process analysis". E-book Available

John P. Miller, 2002. Cerdas di Kelas Sekolah Kepribadian, Terj Abdul Munir Mulkhan, Yogyakarta: Kreasi Wacana

Munandar, Utami, 2012. Pengembangkan kreativitas Anak Berbakat. Jakarta: Rineka Cipta.

Nurdin, M \& Ishak, A., 2001. Moral dan kignisi islam. Bandung: CV. Alfabeta

Okpara, Friday O., 2007. The Value of Creativiti And Innovation In Enterpreneiurship. Journal of Asia Entrepreneurship and Sustainability No 
reproduction or storage, in part or in full, permitted without prior permission, Vol 3, no 2, summer 2007

O'Brien K.M., 2003. Measuring Career Self efficacy promoting Confidance and Happines an Work.

Suharman, 2011. Kreativitas teori dan pengembangan. Surabaya: Laros

Ward, Thomas B., 2003. Cognition, creativity, and entrepreneurship. Center for Creative Media, University of Alabama, Tuscaloosa, vol 19 sammer 173188

Zimmerman, B., 2002. Becoming a Self-Regulated Learned: An Overview. Journal of Educational Psychology, 41, 67

Zohar, danah \& Ian marshal, 2005. SC, Spiritual Capital: Memberdayakan SQ Di Dunia bisnis. Bandung: PT.Mizan Pusta

Yulia, yuyun, 2010. Efektifitas pelatihan AMT (Achievement motivation training) dengan pendekatan Spiritual terhadap peningkatan efikasi diri mahasiswa. Tesis Fakultas Ilmu Sosial. UIN Sunan Kalijaga Yogyakarta. 